5. URL: https://mobile.twitter.com/RomArchable/status/13280099 85322835968? fbclid=IwAR11378TNWaviKOyO1 mvvdSUfHrLyaBRgKj2miJaRdI_6wOtSOE3q272y0 (дата звернення 21.11.2020)

6. Потебня О. Естетика i поетика слова [Збірник] / Упоряд. І. В. Іваньо, А. І. Колодної ; Пер. А. Колодної. Київ : Мистецтво, 1985. $302 \mathrm{c}$.

7. Соссюр Ф. Курс общей лингвистики / Перев. франц. А. М. Сухотина. М. : Логос, 1999.

8. Пирс Ч. Избранные философские произведения. М.: Логос, 2000. $412 \mathrm{c}$.

9. Дядюх-Богатько Н.Й. Комунікативний дизайн: крізь призму семантики. Поліграфічні, мультимедійні та WEB-технологї̈ / Матеріали III міжнар. наук.-техн. конф. Львів : УАД, 2018. С. 255-258.

10. D`Alleva, Anne. Methods \& Theories of Art History. London: Laurence King Publishing Ltd, 2005. 186 p.

11. Ковальчук, Н.П. Смайлики як візуально-смислові конструкції культури віртуального спілкування. Наукові записки / Нац. ун-т Острозька академія; відп. ред.: І.Д. Пасічник. Острог, 2011. Вип. 21. C. 50-57.

DOI https://doi.org/10.30525/978-9934-26-004-9-86

\title{
ПІДГОТОВКА МАЙБУТНІХ ХУДОЖНИКІВ-МАГІСТРІВ ДО ЗАСТОСУВАННЯ ТЕХНІК МОНУМЕНТАЛЬНО-ДЕКОРАТИВНОГО МИСТЕЦТВА
}

\author{
Завгородній Р. В. \\ аспірант кафедри теорії та історії мистецтвва \\ Київської державної академії декоративно-прикладного мистеитва \\ і дизайну імені Михайла Бойчука \\ м. Київ, Украӥна
}

Соціально-економічні зміни, що відбуваються в сучасному суспільстві, вимагають кардинального перегляду освітнього процесу в мистецьких ВНЗ, виявлення виникаючих суперечностей, пошуку шляхів їх подолання, розробки нових концептуальних підходів до проектування змісту мистецької освіти, розроблення освітніх програм і навчальних планів, які сприятимуть підвищенню ефективної фахової підготовки майбутнього художника монументально-декоративного мистецтва. 
Сучасні вимоги до випускників мистецьких ВНЗ достатньо високі, зокрема, професіограма митця містить чимало різноаспектних складових. При цьому, важливим компонентом залишається наявність науководослідницької складової. Не менш важливою складовою, що грунтується на засадах філософського осмислення демократизації, гуманізації, фундаменталізації та глобалізації, спрямованої на формування інтегрованих знань та комплексних умінь, творчий розвиток i національне виховання особистості, $\epsilon$ художньо-трудова підготовка майбутніх художників.

Вона містить широкий спектр узагальнених художньо-проектних, технологічних і методичних знань, умінь та компетентностей. При цьому ієрархічно провідне місце займають художньо-проектні знання й уміння, які мають високу міру узагальненості та перенесення, відображають найбільш суттєві ознаки об'єктів і явищ навколишньої дійсності, характеризуються наявністю широких внутрішньосистемних $\mathrm{i}$ міжсистемних інтеграційних зв'язків, а головне - виконують творчу функцію. У зв'язку з цим, якість професійної підготовки майбутніх художників багато в чому визначається тим, наскільки глибоко вони оволоділи художньо-проектними знаннями й уміннями та компетентно підготовлені до організації творчої предметно-перетворювальної діяльності в умовах професійних ситуацій [1].

Тому на мистецьких факультетах вищих навчальних закладів домінантою навчально-виховного процесу поступово стає підготовка компетентного фахівця, спроможного усвідомлювати та реалізовувати фахові знання в загальному соціокультурному контексті. Проте на практиці нерідко переважає тенденція до підготовки фахівця, який засвоїв лише уміння й навички класичної діяльності. При цьому значно менше уваги приділяється вихованню в студента художньопедагогічного мислення, оволодінню ним інноваційними технологіями, формуванню здатності застосовувати знання й уміння в процесі розв'язання конкретних професійних ситуацій.

Наразі практично відсутні дослідження, присвячені системному вивченню процесу навчання художнього проектування майбутніх художників-технологів як цілісного педагогічного явища. Осмислення теоретичного підгрунтя та вивчення практичного досвіду навчання художнього проектування художників-монументалістів уможливили виявлення низки суперечностей між:

- усвідомленням важливості гуманізації вищої мистецької освіти, спрямуванням навчального процесу на розвиток творчої особистості у художньо-проектній практиці та відсутністю відповідних теоретикометодологічних засад і науково-методичного інструментарію; 
- змінами у змісті фахової підготовки сучасних учителів технологій, зокрема ії проектно-технологічної складової, та відсутністю концепції та моделі методичної системи навчання художнього проектування;

- якістю навчання художнього проектування майбутніх художниківмонументалістів й організаційних засад інноваційного характеру, спрямованих на створення розвивального середовища творчої художньопроектної діяльності в умовах мистецького ВНЗ.

Отже, сучасний стан вітчизняної мистецької освіти характеризується, 3 одного боку, прогресивними тенденціями, пов'язаними з необхідністю здійснення освітнього процесу на основі врахування теоретикометодологічних засад творчого розвитку особистості митця в процесі створення художніх проектів і втілення їх у матеріалі, а 3 іншого нездатністю забезпечити виробничу практику художникаммонументалістам, котрі володіють розвиненими художньо-проектними знаннями й уміннями та досвідом організації проектно-технологічної діяльності [2].

Подолання вище зазначених суперечностей передбачає: 1) теоретичне обгрунтування концепції навчання художнього проектування майбутніх художників-технологів; 2) розробку моделі методичної системи навчання художнього проектування майбутніх художників-монументалістів, а також змісту та методики, здатних реалізувати ії основні складники i компоненти; 3) визначення психолого-педагогічних основ, науково обгрунтованих організаційно-педагогічних умов i діагностичного інструментарію формування у майбутніх митців художньо-проектних знань та вмінь [2].

\section{Література:}

1. Курач М. С. Компоненти педагогічної концепції формування цілісного художньо-проектного знання майбутнього вчителя технологій. Проблеми підготовки сучасного вчителя: зб. наук. праць Уманського держ. пед. уні-ту імені Павла Тичини / М. С. Курач. - Умань: ФОП Жовтий О.О., 2014. - С. 49-54.

2. Курач М. С. Розвиток творчих здібностей студентів у процесі художньо-проектної діяльності. Наука і освіта: наук.-практ. журнал Південного наукового центру НАПН України / М. С. Курач. - Одеса, 2014. - (7). - C. 111-115. 